\title{
Woodrow Wilson como Administrador (")
}

\author{
HENRY A. TURNER \\ (Tradução de RAIMUNDo X $\mathrm{X}_{\text {AVIER DE }} \mathrm{M}_{\text {ENEZES }}$ )
}

\begin{abstract}
$\mathrm{V}$ INTE e oito de dezembro de 1956 assinalou o centenário do nascimento de WoodRow WiLSON, um dos presidentes mais complexos que até hoje nos governaram. Poucos contribuiram tão significativamente em campos tão variados, e apresentaram tal número de interessantes facetas em sua perscnalidade. Wilson, o sexto presidente da American Political Science Association, é conhecido como ilustre cientista político, em virtude de suas obras Conǵressional Government, The State e Constitutional Government in the United States, a'ém de numercsos ensaios sôbre o mesmo assunto. E tido como historiador em atenção aos seus trabalhos History of the American People e Division and Reunion. Sua ação como Presidente da Universidade de Princeton bem como as manifestações literárias sôbre temas educacionais granjearam-lhe fama de educador. As reformas promovidas sob sua crientação, quando Governador de New Jersey, distinguem-no como um dos Chefes de Executivo estaduais mais notáveis, dentre os de sua geração. Em virtude da legislação federal promulgada em seu período de govêrno, de sua liderança durante a Primeira Grande Guerra e de sua advocacia em favcr da Liga das Nações, pode êle figurar como um de nossos maiores Presidentes.
\end{abstract}

Em 1889 - quando ainda WILSON não era conhecido como educador e estava longe de ganhar notoriedade no govêrno de New Jersey e na Presidência da República - o Professor HERBERT BAXTER ADAMs, da Universidade Johns Hopkins, disse a um grupo de alunos que a Sociedade haveria de lucrar grandemente com as contribuições que WOODROW WILSON iria fazer à administração. (1) Sem dúvida o professor ADAMS sentiu que possuia sólidas razões para expressar essa crença, pois, naquele anc, era WoodRow WILSON apenas um estudante promissor do mais novo ramo da ciência política: a admi-

(*) Tradução autorizada do ensaio Woodrow WILson as administrator, publicado pela Public Administration Review (Outono, 1956), com o qual foi comemorado o cen tenário de nascimento do grande Presidente norte-americano. O autor é Professor Assistente de Ciência Política da Universidade da Califórnia (Santa Barbara College).

(1) Seminar Records of Professor AdAMS, november 8, 1889 by the secretary, T. IYENAGA. The Johns Hopkins University Library. "Pela interferência dos mestres", acrescentou o Dr. ADAMs, "grandes progressos advirão para a sociedade, tal como está fazende o Dr. Gould pela reforma tarifária, o Dr. SHAw pela reforma municipal e o Dr. WiLson pela reforma da administração". 
nistraçấo pública. Nosso propósito, neste artigo, é determinar o lugar de WILSON no desenvolvimento histórico da administração pública.

\section{Precursor do Estudo de AdministraçÃo}

O interêsse de WILson pela administração foi desdobramento de outro, mais amplo, por assuntos políticos e de govêrno, desde cedo revelado. Embora EDMUND BURKE tenha por certo concorrido, mais do que qualquer outro pensador, para plasmar-lhe a filcsofia política, foi WALTER BAGEHOT quem, preponderantemente, the guiou o pensamento para os estudos de administração e de govêrno comparados. (2) Em 1879, Wilson, já no último ano de Princeton, escreveu um artigo sob o título Govêrno Parlamentar nos Estados Unidos, onde deixou clara a influência da obra $A$ Constituição Inǵlêsa, de BAGEHOT. Neste artigo, publicado em The International Review, esclareceu, pela primei. ra vez, algumas de suas idéias básicas de natureza política e administrativa. Com efeito, sustentava ali que uma forte liderança do Executivo, em cooperação íntima com o Congresso, era o que havia de mais necessáric a um Go. vêrno eficiente, vigoroso e responsável. Segundo pensava o jovem WILson, os Estados Unidos poderiam adotar essa espécie de govêrno, abolindo a separação dos poderes e aceitando, algo modificado, o sistema britânico. Ao Presidente facultar-se-ia a escolha do Gabinete entre os membros das duas Casas do Congresso. WILson divisou inúmeras vantagens administrativas a retirar dessa mudança política. Com os membros do Gabinete participando duplamente do Govêrno, como ministros executivos e líderes parlamentares, ter-se-ia uma legislação mais adequada e inteligente. De resto, sob tal regime, poderse-ia fazer face às necessidades administrativas com maior "adequabilidade $\theta$ compreensãc". Ainda mais: sendo os Ministros de Estado membros do Con. gresso, poderia êste, interpelando-os e com êles debatendo os assuntos adminis. trativos, não apenas controlar, com maior eficácia, o funcionamento das repartições, senão também, com melhor resultado, educar a opinião pública em questões de política governamental. Ao mesmo tempo, aos Ministros, como participantes ativos nos debates, seria possível proteger seus ministérios contro críticas irresponsáveis e injustas.

Depois de formado pela Universidade de Princeton, WiLson bacharelou. se em Direito pela de Virginia e abriu um escritório de advocacia em Atlanta, na Georgia. Decorrido um ano de insucessó, porém, inscreveu-se na Univer. sidade Johns Hopkins, a fim de preparar-se para o exercício do magistério se. cundário. Um mês após, escreveu que desejava prosseguir na "linha de estudo", que fôra seu

“... principal divertimento e prazer nas horas vagas dos últimos cinco ou seis anos, ou seja, o estudo de política comparada. Já examinei suficientemente a organização administrativa da Ingla-

(2) A influência de BURKE e BAGEHOT sôbre WiLson dificilmente pode ser exagerada. Anos mais tarde, o Coronel Edward House escreveu em seu diário que WiLson se dizia "discípulo de BURKE e BAGEHOT" e estava sempre citando "um e o outro". CHARLES Seymour, ed., The Intimate Papers of Colonel House (4 vols.; Houghton Mifflin Co.. 1926-28) I. 121. 
terra e a de nosso próprio país para bem entendê-las, e era meu grande desejo fazer estudo semelhante dos governos nacionais (bem ccmo, talvez, dos de âmbito local) da França e da Alemanha".

WILson imediatamente dedicou-se de corpo e alma à nova tarefa e, com poucos meses de matriculado na Universidade, publicou o artigo Govêrno em Comissão ou de Gabinete? e começou a escrever seu primeiro livro, intitulan. dčo Govêrno Parlamentar.

No começo de 1885, pouco depois do aparecimento de Govêrno Parlamentar, WILson voltou-se para o que chamou a ciência da administração. O Estudo da Administração, que constitui a primeira prova importante dêsse interêsse, só fci publicado, contudo, dois anos e pouco depois, em junho de 1887. E êste ensaio uma de suas obras políticas mais originais. (*) Enquanto Govêrno Parlamentar e os primeiros ensaios advogando o parlamentarismo para os Estados Unidos se baseavam, em grande parte, nos trabalhos de BAGEHOT etc., $O$ Estudo de Administração parece não se ter inspirado em nenhu. ma fonte de natureza semelhante. Contudo, as idéias ali expressas se arrimam. primordialmente, em conclusões de leituras, (4) por isto que, ao escrever aquêle ensaio, WiLsoN ainda não realizara qualquer observação pessoal do funcionamentc efetivo do Govêrno. (5) Ao iniciar os estudos de administração, afirmou êle: “... Se escrevi Govêrno Parlamentar sem visitar Washington, muito mais posso escrever sôbre a ciência da administração sem que venha a fazê$10 "$. (6)

Há provas de que as opiniões de WILsON mudaram consideràvelmente. desde quando elaborou os primeiros rascunhos do ensaio até sua publicação em forma definitiva. De início o título era Notas sôbre Administração, mudan. do depois para $A$ Arte de Governar e, finalmente, para $O$ Estudo da Adminis.

(3) Wilson a Ellen Axson, em 16 de outubro de 1883, citado em RAY STANNARD BAKER, Woodrow Wilson: Life and Letters (8 vols.; Doubleday, Page \& Co. 1927-1939) I, 174 .

(*) Está traduzido para o português: O Estudo da Administração, Rio de Janeiro, EBAP, 1955, fazendo parte da série de Cadernos de Administração Pública. (Nota do trad.).

(4) E' impossivel, naturalmente, determinar-se de modo exato o que WILson havia lido antes de escrever êsse ensaio, mas, em suas notas de aula para o curso de administra. ção, inclui uma bibliografia onde arrolou seis livros de autores alemães e sete franceses, todos escritos anteriormente a 1887, quando apareceu $O$ Estudo da Administração. Essas notas de aula encontram-se na Coleção Woodrow WILson, na Biblioteca do Congresso, a qual, doravante, será referida como Coleção Wilson.

(5) Wilson, possìvelmente, recebeu influência e estímulo do Professor Richard T. ELY que retornara não havia muito, de estudos na Alemanha. Durante o segundo período escolar (1884-85), ELY pronunciou conferências sôbre métodos administrativos na Ingla. terra, Alemanha e França. (Circular da Universidade Johns Hopkins, de julho de 1885 . Baltimore). "Quando falei da importância da administração", escreveu ELY posteriormente, "senti que havia desprendido uma faísca e ateado uma chama em WrLson". RICHARD T. ELy, Ground under Our Feet, Mac-Millan Co., 1938 p. 114.

(6) Wilson a Ellen Axson, em 22 de janeiro de 1885, citado em BaKer, op. cit. I. 259 . 
tração. (7) Pode-se nctar a transformação das idéias de WILson sôbre a matéria, observando-se que, na forma primitiva do artigo, êle escreveu: "Suponho que nenhuma grande descoberta de método virá a ser feita em administração". Todavia, no texto final, afirmou que "... a criação e os estudos administrativc’s são imperiosamente necessários..."

Na verdade, Woodrow WILson foi, nos Estados Unidos, um pioneiro dos estudos de administração. O citado artigo é considerado como um notável esfôrço para abrir novos caminhos, convindo notar que, mesmo antes de publicá-lo, Wilson já era geralmente acatado no ensino dessa matéria. Em 1886 o Professor ADAms convidou Wilson para dar um curso de administração, de três anos, na Universidade Johns Hopkins. WILson manteve-o, como confe. rencista visitante, por dez anos, (8) muito embora nesse período se tenha transferido do Bryn Mawr College para a Universidade Wesleyana e daí para a Universidade de Princeton. Durante os três primeiros anos em que ensinou em Princeton, ministrcu WILsoN um curso sôbre administração, no qual utili. zou as conferências proferidas no primeiro ano do curso prelecionado na Universidade de Johns Hopkins. (9) O papel de WILson como pioneiro se evidencia pelo fato de que, quando lecionava administração em Princeton e Jchns Hopkins, apenas duas outras escolas nos Estados Unidos ofereciam cursos similares. (10) $\mathrm{E}$, ao tempo em que foi escrito o primeiro livro didático norteamericano sôbre administração, WILsoN já vinha há seis anos pronunciando conferências sôbre o assunto. (11)

WILSON ganhou fama ràpidamente de conferencista capaz e pelo menos um mestre the solicitou a ajuda no preparo de um curso sôbre administração. Sua resposta ao Professor AlBert Bushnell HART, o solicitador dessa assis. tência, indica a amplitude da matéria incluída no curso:

"Oxalá fôssem minhas conferências sôbre o assunto, pronunciadas na Universidade Johns Hopkins, de tal natureza e forma que lhe pudessem servir de auxílio no planejamento de um curso sôbre

(7) O rascunho primitivo do ensaio encontra-se na Coleção Wilson. $O$ estudo da Administração foi publicado em 2. ${ }^{\circ}$ Political Science Quarterly 197-222 (junho-1887).

(8) ADAMS explicou que o compromisso era "para vinte e cinco conferências em cada ano, sem repetição". Citado em W. Stull Holt, ed. Historical Scholarship in the United States, 1871-1901: As Revealed in the Correspondence of HERBERT B. ADAMS (The Johns Hopkins Press, 1938), pp. 87-99, ver também, carta de AdAMs a Wilson, de 4 de junho de 1890 na Coleção Wilson.

(9) O curso figura nos programas da Universidade de Princeton correspondentes a 1890-91, como se segue: "Administração. Conferências e leituras subsidiárias. Duas horas por semana... Opcional para estudantes nos últimos anos e aberto a alunos já formados". O curso permaneceu nos programas durante quatro anos letivos de 1890-94, mas, de acôrdo com os registros de WrLson, na Biblioteca do Congresso, só foi êle ministrado nos três primeiros anos dêsse período.

(10) Anna Haddow, Political Science in American Colleges and Universities, 16361900 (D. Appleton-Century Co., 1939), pp. 180, 181, 187, 194 e 195. As escolas eram as Universidades de Columbia e Pensilvânia.

(11) O primeiro livro didático sôbre administração foi o de Frank J. GoodNow, intitulado Comparative Administrative Law, 2 vols. G. P. Putnam's Sons 1893. 
Govêrno e Administração. Ocorre, porém, que o meu, êste ano, sendo apenas a primeira etapa de um curso de três anas, em grande parte teve caráter geral e não fêz qualquer referência sistemática ou específica à nossa organização administrativa. Relacionou-se, antes, com as questões gerais e teóricas da ciência da administração. No próximo anc e no subseqüente, preocupar-me-ei com os sistemas concretos e as discussões práticas. Além disso, nunca escrevo minhas conferências, de modo que possuo, apenas, simples notas esquemáticas. Estas estarão ao seu inteiro dispor, se as considera de alguma utili. dade. (12)

Foi, assim, que WoODRow WILsON se iniciou auspiciosamente no campo da administração. Era de esperar-se que os louvores que the foram tributados pelos seus contemporâneos atuassem como estímulo a novas emprêsas, mas não deu prosseguimento a êsses primeiros êxitos com atividades mais vastas no ensino ou ccm trabalhos subseqüentes. Interrompeu o curso de Princeton, depois de ministrá-lo apenas por três anos, mantendo o de Johns Hopkins por um decênio. Embora os dois últimos livros qưe escreveu - $O$ Estado e o Govêrno Constitucional nos Estados Unidos - e alguns outros ensaios contenham algo de seu pensamento administrativo, WILsoN não dedicou nenhum trabalho ao assunto depois de $O$ Estudo da Administração.

\section{Contribuições e Práticas Administrativas}

A primeira oportunidade de WILson pôr à prova suas idéias administrativas ofereceu-se, em 1902, quando foi escolhido Presidente da Universidade de Princeton. Os primeircs anos naquele cargo foram assinalados por singular êxito, ocorrendo, sob sua liderança, notáveis realizações. Ao dar execução aos planos que elaborou, pôde reorganizar a estrutura acadêmica e administrativa da Universidade, modificando-lhe os métodos de instrução, elevando o nível de ensino, reformando o corpo docente e acrescendo, materialmente, o patri. mônio da Universidade. Todavia, devido em grande parte à sua atitude intransigente em discussões sôbre planos elaborados para os cursos superiores, teve que enfrentar forte oposição. Conseguintemente, a êstes anos de êxito inicial sucedeu um período cheio de reveses e frustrações, durante o qual a maioria em Princeton se viu cindida em fervorosos adeptos e adversários extremados de suas idéias.

Essas controvérsias, porém, concorreram para tornar WILSON figura nacionalmente conhecida e, de maneira indireta, levaram à sua escolha como Governador de New Jersey em 1910. Serviu apenas dois anos do mandato trienal para o qual havia sido eleito, renunciando em 28 de fevereiro de 1913, a fim de tornar-se Presidente dos Estados Unidos. Entretanto, julgado por qualquer critério, fez administração notável. Como Governador deixou claro o propósito de pôr em prática no Estado a teoria de liderança executiva que

(12) Wilson a Albert Bushnell Hart, em 22 de maio de 1891, Coleção Wilson. Esta carta deixa entrever que WiLson deve ter exercido considerável influência no planejamento dos primeiros cursos de administração. 
idealizara para aplicação na esfera federal. Presidiu ao preparo e à aprovação de um programa legislativo de reformas sociais, que o distinguiram como um dos mais bem sucedidos governadores do país. Tentou em seguida, reorganizar o sistema administrativo estadual e, ao tempo em que deixou o Govêrno, advogava uma nova Constituição para o Estado, a qual introduziria ali um regime do tipo parlamentar. (13)

Como Presidente dos Estados Unidos, Wilson - utilizando muitas das técnicas, instituições e métodos políticos com que se havia familiarizado quase conseguiu para si o poder e a influência que acreditava desejáveis em caráter permanente. Restakeleceu o hábito de proferir pessoalmente suas mensagens presidenciais ao Congresso. (14) Instituiu, pela primeira vez, em caráter regular, as entrevistas de imprensa e procurou esforçadamente prcmover a orientação da opinião pública. Excetuado JEFFERSON, mais do que qualques dos seus antecessores, WiLSON serviu-se das reuniões partidárias preliminares como expediente para obter um sólido apoio político ao seu programa legislativc. Em estrita conformidade com a sua teoria de liderança executiva desde cedo formulada, exerceu influência sôbre tôdas as fases da elaboração das leis . Planejava os programas legislativos; (15) juntamente com os assistentes, tomava parte ativa na redação dos projetos; (16) e depois de apresentados, usava de recursos vários para thes obter a aprovação. Graças em grande parte aos seus esforços, foi aprovada em seu Govêrno uma legislação mais construtiva do que durante o mandato de qualquer outro Presidente, de GEORge Washington a Franklin Roosevelt. (17) Por seis anos Wilson dirigiu e contrciou o Congresso de maneira até então não igualada. Todavia, quando os Democratas perderam a maioria legislativa nas eleições de 1918, ficou WILson privado do instrumento mais importante através do qual havia exercido sua liderança.

A legislação aprovada sob sua influência nos primeiros anos do mandato, tanto quanto sua maneira de executar cs deveres presidenciais, tiveram efeito

(13) Henry A. TuRner, Woodrow Wilson and the New Jersey Legislature: 74 Procredings of the New Jersey Historical Society 21-49 (January, 1956) .

(14) Ao entregar ao Congresso sua primeira mensagem, a 7 de abril de 1913, WILson quebrou uma tradição estabelecida por JEFFERson cento e quinze anos passados.

(15) O Diretor Geral dos Correios, Albert S. BuRLeson, mais tarde escreveu: "Durante seis anos, nós, invariàvelmente, pusemos em prática êsses programas como esboçados por Woodrow W'Illson". Albert S. BurLeson a Josephus Daniels, em 19 de fevereiro de 1926, Documentos Ray Stannard Baker, B.blioteca do Congresso. Daqui por diante serão referidos como Documentos Baker.

(16) WILson foi o primeiro Presidente a insistir em que o Chefe Executivo e seus subordinados deviam ter o privilégio de elaborar um apreciável número de medidas legislativas, devendo o Congresso aprová-las, tais como foram elaboradas. Norman J. Small, Scme Presidential Interpretations of the Presidency (Johns Hopkins Press, 1932), p. 178. O Sr. Small afirmou que, em outras administrações, os membros do Gabinete “.... apresentavam nas salas das comissões, já inteiramente prontas, propostas legislativas de seus Supremos Magistrados; todavia, indubitàvelmente, devido ao mêdo de que o Congresso sentisse sobremodo aguda essa usurpação de competência não era freqüentemente que se recorria a essa prática".

(17) HenRy A. TuRner, Woodrow Wilson: Exponent of Executive Leadership, The Western Political Quarterly 96-115 (March, 1951). 
profundo e duradouro sôbre as instituições e os métodos administrativos do país. Uma das consequiências mais importantes de seu govêrno foi o enorme desenvolvimento das atividades do Estado. Durante a guerra o número de funcionários burocráticos elevou-se a cifras sem precedentes e, depois dela. não obstante o decréscimo dos encargos federais, a máquina administrativa não mais voltou à situação anterior. C crm WILson, o contínuo movimento de centralização foi acelerado. Aprovaram-se leis que, por um lado, ampliavam em detrimento dos Estados o âmbito de ação do poder federal e, por outro, lhe estendiam a autoridade a setores anteriormente não regulamentados. Para dar uma idéia da extensão dessa autoridade a esferas anteriormente privativas dos Estados, basta citar o Federal Reserve Act que, de modo indireto, pôs os bancos estaduais sob contrôle federal; o National Defense Act, de 1916, que tornou as milícias estaduais subsidiárias das Fôrças Armadas, ou qualquer uma das medidas sôbre a concessão de subvenções aos Estados, tais como o Federal Aid to Roads Act, o Smith-Lever Act, ou o Smith-Hughes Act. (18). Para exemplificar o alargamento do contrôle estatal sôbre questões que tinham escapado até entãc à regulamentação, cumpre mencionar o Federal Trade Act, o Clayton Anti-Trust Act, o La Follette Seaman's Act,' o Federal Transportation Act, de 1920, e o Federal Power Act.

Outro fato, com reflexos administrativos, ocorrido no Govêrno de WiLson, diz respeito ao elevado número de organizações autôncmas criadas na administração pública federal. Na época de sua posse, a Comissão do Serviço Civil e a Comissão de Comércio Interestadual eram os dois únicos órgãos dêsse gênerc, existindo como companhia estatal apenas a ferrovia do Panamá. (19) Foi com êle que se criaram numerosas comissões, conselhos, administrações e companhias estatais. Nesse conjunto a Federal Trade Commission, a Tariff Commission, a Federal Power Commission e a United States Shipping. Board tornaram-se partes permanentes da estrutura administrativa federal. Embora muitas das outras repartições autônomas tivessem vida curta e caráter de emergência de guerra, serviram como úteis modelos de organização ao serem criadas certas agências para combater a depressão e levar a têrmo a Segunda Grande Guerra.

Já em 1908 WILson escrevera que o Gabinete devia ser "um corpo executivo e não político". Ao tornar-se Presidente, pôs em prática, sob forma ligeiramente modificada, essa primeira teoria. Nunca chegou a escolher um membro de seu Gabinete pelo simples motivo de desejar aconselhar-se com êle sôbre prcblemas políticos; todavia, vários fatôres dessa natureza contribuiram para a escolha de muitos de seus ministros. Também levou em conta, ao fazer certas nomeações, a necessidade de terem representação, diferentes regiões geográficas do país. Na composição do Gabinete preponderaram razões administrativas; e em cada Ministério WiLson nomeou pelo menos um

(18) Sete leis sôbre concessão de subvenções foram sancionadas durante a adminis. tração de WILson, sendo oito o total das aprovadas pelos seus antecessores. LEONARD D. White, Trends in Public Administration, Mc Graw-Hill Book Co., 1933, pp. 29,33-48.

(19) Ibid. p. 171. The First Bank of the United States foi a unica companhia estatal criada para operar serviços públicos. 
dos seus funcionários mais graduados em virtude de sua "aptidão especial para o importante pôsto" (20) indicado.

O grau de autonomia concedido por Wilson aos chefes dos diversos departamentos executivos variava de época para época e de uma para outra repartição. Aos Ministros do Extericr WILson conferiu muito pouca liberdade no trato das relações internacionais e, durante a Guerra, manteve-se em con. tato íntimo com os Ministros militares. Houve tempos em que trabalhava em estreita ligação com o Ministro da Fazenda e, às vêzes, com um cu dois dos outros membros integrantes do Gabinete. Mas, consideradas essas exceções, WILSON assegurava aos seus Ministros larga margem de independência na administração de seus respectivos Ministérios.

Ao determinar o grau de contrôle que devia exercer sôbre seus Ministros, WILson fazia distinção entre cs problemas gerais de politica administrativa $\theta$ os de gestão interna. Embora em ambos os casos lhes desse bastante liberdade, estava subentendido que as diretrizes mais gerais seriam determinadas por êle de comum acôrdo com os respectivos Ministros, ao passo que a maior parte das questões de administração interna ficaria ùnicamente a critério de cada um dos membros de seu Ministério. David F. Houston, que integrou, durante oito anos, o Gabinete de Wilson, tempos depois escreveu:

"Parti do princípic de que seu desejo era que eu assumisse tôda a responsabilidade que julgasse conveniente e o libertasse, ao máximo, de preocupações. Também nunca precisei recorrer a muitas palavras para fazê-lo compreender as necessidades. Grande número de assuntos eram ràpidamente tratados nas reuniões ministeriais." (21)

Um exame de suas diretrizes de administração de pessoal, quando Presidente, revela falta de conformidade entre as primeiras teorias e os métodos ulteriores de caráter administrativo. Durante todo o período governamental, viu-se em face do dilema de harmonizar as exigências políticas com o desejo de colocar em cada pôsto o homem adequado. WILSON acreditava, invariàr velmente, que o mérito de um govêrno dependia, em grande parte, da inteligência e da capacidade de seus funcionários e que o uso do empenho paitidário no serviço público era de efeito imoral. Todavia, muitas das nomeações por êle realizadas só se podem explicar na base da conveniência política. Embora haja esposado a teoria, segundo a qual os empregados públicos devem ter estabilidade, enquanto bem servirem, muitos dêles foram demitidos nos dois ancs de seu mandato. (22) WILson de há muito advogava modificações

(20) Woodrow Wilson, Constitutional Government in the United States, Columbia University Press, 1908 , p. 70.

(21) Houston à Sra. Woodrow Wilson, em 1 de abril de 1925, Documentos Backer. JoSEPHUS DANIELS, que serviu como Ministro da Marinha durante tôda a administração de WiLson, escreveu: "Desde o início, Wilson deu aos membros do Gabinete liberdade na direção dos assuntos de interêsse dos respectivos Ministérios. Nenhum Presidente abstevese tanto de estorvá-los mediante nomeação de seus subordinados. Mantendo-os responsáveis, dava-lhes liberdade, confiança e cooperação". Citado em JosephuS DANIELS, The Life of Wilson, The John C. Winston Co., pp. 139-140.

(22) Em viste de os Democratas ficarem longo tempo afastados do poder, o número de Republicanos recolocados pelos sucessores de WILSON não foi, porém, excessivo. 
administrativas e, durante os dois últimos anos anteriores ao seu ingresso na Casa Branca, exerceu o cargo de Vice-Presidente da Liga Nacional de Reforma do Serviço Civil; apesar disso, no govêrno tomou poucas iniciativas com respeito a reformas de pessoal na esfera da União. Nesse particular, sua mais notável obra foi tornar extensivo o sistema do mérito aos agentes de correio de primeira, segunda e terceira classes. (23)

Houvesse Herbert BAXter AdAMs analisado as realizações de WiLson na época da morte dêste, em 1924, sentir-se-ia envaidecido pelćs êxitos que o antigo aluno e colega alcançara, mas teria concluído, certa e forçosamente, que seu prognósticc, feito trinta e cinco anos atrás, não se confirmara. Isto porque, embcra Wilson houvesse introduzido no Govêrno dos Estados Unidos inovações prenhes de conseqüências administrativas de longo alcance, não chegou a realizar a "reforma administrativa" vaticinada por ADAMs. Como Presidente da República, WiLson esforçou-se para que se reorganizasse a estrutura administrativa federal e conseguiu fôsse aprovado o Overman Reorganization Act, que havia sido preparado sob a direção de um seu antigo discípulo, o Ministro da Guerra, Newton D. BAKer. (24) Manifestou sempre considerável interêsse na eficiência e economia das operações governamentais e defendeu o emprêgo de um sistema de orçamento nacional, (25) mas não deixou qualquer reforma administrativa de vulto ligada a seu nome.

\section{CONFLITO DE CIRCUNSTÂNCIAS E PERSONALIDADE COM AS PRÁTICAS E TEORIAS ADMINISTRATIVAS}

As contradições, por demais evidentes na personalidade e na carreira pública de WILsoN, tornam extremamente difícil uma apreciação definitiva de seus dotes como administrador. Poucos Presidentes se sujeitaram a ter os seus atos tão minuciosamente esquadrinhados, mas com resultados tão pouco satisfatórios. O fatc incontestável é que êle foi um dos indivíduos mais enigmáticos e paradoxais dentre os que têm atuado no cenário político americano, de onde as interpretações contraditórias acêrca de sua personalidade, (26) que não iremos aqui tentar conciliar ou justificar. Todavia, as semelhanças e os paralelismos, claramente discerníveis ncs três postos da carreira administrativa de Wilson, indicam que se deve atender a certos traços de emotividade

(23) WILson determinou que fôsse selecionado, para cada cargo, o indivíduo com a melhor fôlha de serviço ao Estado.

(24) Frederck Palmer, Newton D. Baker, America at War, 2.vols., Dodd Mead and Col., 1931, II, 82 .

(25) WiLson vetou o projeto de lei de Orçamento e Contabilidade (Budget and Accounting $A c t$ ) de 1920, porque acreditava inconstitucional o artigo referente a exoneração do Contador-Geral (Comptroller General) por uma simples resolução, aprovada pelas duas Casas do Congresso.

(26) Comparem-se os relatos encomiásticos de JOSEPH Tumulty, Woodrow Wilson as I Knew Him, Doubleday, Page and Co., 1921, e os de Ruth CRANSTon, The Story of Woodrow Wilson, Twenty-eighth President of the United States. Pioneer of World Democracy, Simon and Schuster, $1945 \mathrm{com}$ as mordazes observações críticas de RoBERT EDWARDS AnNin, Woodrow Wilson: A Character Study, Dodd Mead \& Co., 1924, e de William! BAYARD HALE, The Story of a Style, B. W. Hueback, Inc., 1920. 
e de temperamento a fim de avaliar adequadamente seus métodos e teorias administrativas.

Uma obsessão de liderança plasmou muitos dos pensamentos e atcs de Wilson. Desde a sua juventude viveu fascinado pelos fenômenos do poder pclítico e, conscientemente, diligenciou por desenvolver aquelas qualidades e pendores que, segundo pensava, o habilitariam a alcançar um pôsto de comando. Sua teoria da liderança executiva - tomada de empréstimo ao sistema parlamentar britânico - era mais do que simples preceito político: era parte básica de suas idéias filosóficas e alicerçava-se em seu desejo de comandar.

Complementando essa aspiração de mando, distinguia-se WiLSon também pela tendência às composições lógicas e sistemáticas, que o levavam a provi. dências reorganizadoras. Tentou melhorar as relações formais de pràticamente todos os grupos sociais com que entrcu em contato. No transcurso de sua vida, escreveu umas quatorze constituições, cuja importância variava dos regulamentos de clubes de debates até a Carta da Liga das Nações.

Uma aptidão intelectual superior foi um dos fatôres positives que leva. ram WiLson ao triunfo. (27) Seja como administrador, seja como político, sua inteligência brilhante e seu poder de prolongada concentração revelaramse de valor inestimável. Seu espírito sagaz e penetrante poder de imaginação eram ainda cis instrumentos com que preparava planos e mobilizava fôrças. Possuia aguda capacidade analítica, que the facilitava a decomposição dos problemas mais complexos em partes integrantes, e sua maneira de discutir firmando princípios básicos ou realçando causas - permitia-lhe localizar imediatamente o ponto central de qualquer questão intricada. WiLson era essencialmente lćgico, sisterrático e metódico, tanto ao formular como ao executar uma política. Estabelecia seus planos com o cuidado e a precisão próprios a um engenheiro ao construir máquina complicada, e os executava com o impulso, energia e firmeza de propósitos de um reformador religioso.

Embora, de um modo geral, considerem WILson como tendo tido capacidade criadora, os planc's que formulava não eram habitualmente originais, mas, sim, resultados da assimilação e do aproveitamento de idéias com as quais havia entrado em contato. BuRLESON, uma vez, observou: "Êle não criava; organizava". (28) Possuia a habilidade de sintetizar planos e idéias e de organizar os meios necessários à plena frutificação dêsses planos. Assim, ao passo que se credita, com justiça, a WILSON o estabelecimento de instituições como o Federal Reserve System e Liga das Nações, convém acentuar que foi antes pela capacidade de traduzir idéias em fatos, do que pelo seu pensamento criadcr, que chegou a tal resultado.

Conquanto poucos de nossos Chefes Executivos tenham tido a envergadura intelectual de WILSON, possuia êste certos traços mentais sèriamente des-

(27) Charles E. Merriam afirmou, certa vez, que “... achava Wilson um homem com espantosa aptidão, discernimento e facilidade para apreciar qualquer questão". WALGREEN LECTURE, University of Chicago, april 13, 1948.

(28) R.S. BAKer, Memorandum de uma entrevista com Albert S. BurLeson, 17 de março de 1927, Ms. nos Documentos Baker. 
favoráveis a um administrador. Era obstinado e, às vêzes, interessava-se em extremo por um prcgrama em detrimento de outros. Não raro lhe faltava memória, o que explica algumas de suas declarações contraditórias bem como as recomendações insistentes sôbre a transmissão do maior número de detalhes administrativos através de cartas e memorandos. WILSON irritava-se fàcilmente e com dificuldade esquecia uma ofensa. Além disso, deixava-se influenciar por fortes preconceitcs, o que the deformava o habitual bom senso, e só a custo conseguia trubalhar com pessoas que, abertamente, se houvessem oposto à sua política.

Talvez o maior ponto fraco de WiLson, como administrador, fôsse a inaptidão para dirigir e controlar pessoas. Seu idealismo, o sincero desejo de servir à humanidade e a maneira normalmente cortês e atenciosa de tratar os subordinados granjearam-1he $c$ apoio leal e imorredouro de muitos que com êle trabalhavam, (29) mas sua inabilidade em apaziguar os adversários politicos acarretou-lhe a transformação de muitos adeptos potenciais em antagonistas ferrenhos. Embora haja WILSON dominado a tribuna, faltou-1he o magnetismo pessoal de um THEODORE ROOSEVELT ou de um FRANKLIN Roo. SEVELT. Entre amigos íntimos era insinuantemente afetuoso e alegre, mas em meio de estranhos, tornava-se, às vêzes, suspicaz, distante e reservado.

As convicções religiosas de WILson comprometeram-lhe a atividade administrativa. "Ninguém pode compreender WoODROW WILSON", escreveu RAY STANNARD BAKER, "sem conhecer as raízes profundas de sua formação religicsa". (30) Herdou dos ancestrais uma tradição de ensino e prédica da fé presbiteriana e foi educado dentro dos rígidos princípios da Reforma. (31) Sua manifesta crença na predestinação e a fé implícita na Divina Providência se refletem no ar de confiança, tranqüilo autodomínio e determinismo com os quais encarava seus planos e carreira. Certa vez, escreveu: "... Acredito profundamente numa Providência onipotente e não tenho o menor receio de que qualquer plano legítimo possa ser desviado de sua trajetória". (32)

WOODROW WILSON tinha a certeza de que suas diretrizes eram as unicas corretas e que, sem restrições, as devia pôr em prática; não há por que estranhar, pois, se tenha tal certeza transformado na rocha contra a qual tantas ondas de controvérsias vieram rebentar. "Tenho uma consciência que me serve de Timoneiro", declarou WiLson a seu Ministro da Marinha. "Leva-me a realizar minha tarefa e não me deixará sucumbir ante convites tentado-

(29) Basta que se converse com algumas pessoas que hajam trabalhado com WiLson, para sentir-se a lealdade e devoção que êle inspirava a muitos de seus colaboradores. BERNARD BARUCH, por exemplo, disse ao autor dêste artigo: "... operou-se uma modificação em tôda a minha vida quando passei a trabalhar com WiLson". Entrevista, em 22 de junho de 1948, na cidade de Nova York.

(30) BAKER, op. cit. I, 49.

(31) O pai de Wirson, um de seus avós e um tio-bisavô eram todos Pastores Presbiterianos, bem como o foram o pai e um avô de sua primeira esposa. Certa vez afirmou êle: "a tradição rígida dos Reformadores, que se encontra em mim, é como um eco através dos tempos". DANIELs, The Life of Wilson p. 28.

(32) Wilson à Sra. MARY A. Hulbert, em 7 de janeiro de 1912, citado em Baker op. cit. III, 258. 
res". (33) LouIs BRownLOw aventou que a sinceridade das idéias religiosas de Wilson induz a concluir que êle não decidia sôbre uma diretriz e, depois, procurava os meios de justificá-la como a mais justa, mas que, na realidade, procurava o caminho mais justo e, então, considerava como o único rumo de ação correta e moral. (34)

Acreditamos que o desejo de Wilson de sempre seguir um rumo de inflexivel probidade seja a chave que abra o enigma de sua personalidade. Caso seja verdadeira essa hipótese, estará explicada a tendência de Wilson para considerar os adversários de seus planos como igncrantes ou carentes de integridade moral; sua resistência a qualquer conciliação quando se tratasse de "princípios"; a urgência e inevitabilidade com que encarava os próprios planos ou sua propensão a examinar questões de diretrizes como se só o pudessem ser em têrmos de justiça cu de injustiça. Seu senso de retidão moral contribuiu para formar sua dinâmica e superior liderança. Uma pergunta, porém, que inevitàvelmente ocorre, é saber se uma pessoa com o temperamento de um cruzado religioso é o melhor tipo de indivíduo a quem se devam confiar vastos poderes políticos.

Até os começos dêste século WiLson era um partidário declarado de $\mathrm{H}_{\mathrm{A}}$ MILTON, em filosofia política e administrativa, e um liberal do século XIX, nas ideias econômicas. Ainda que por nascimento fôsse democrata do Sul, era Federalista por natureza e hábitc. Além disso, a maior parte de suas idéias econômicas, administrativas e políticas, colheu-as menos na observação e análise pessoais do que na leitura de tratadistas e de homens públicos britânicos dos séculos XVIII e XIX, (35) e foram essas idéias que lhe forneceram a base do liberalismo à moda do século passado. (36) Em tôda a sua vida, Wilson manteve uma filosofia administrativa bàsicamente hamiltoniana. (37) Toda-

(33) DANIELS, The Life of Wilson, p. 27.

(34) Entrevista com o autor dêste artigo, em 23 de julho de 1948, em Washington, D.C. O Ministro Houston, ao aposentar-se, depois de servir oito anos no Gabinete de WILson, escreveu ao Presidente: "Nunca tive a menor dúvida, a qualquer momento, sôbre o princípio que me devia orientar. Eu sabia que só podia ser aquêle pelo qual $\mathrm{V}$. Exa. se guiasse. De há muito o conheço e o tenho acompanhado de perto para saber que só uma questão the interessa: "saber se uma forma de conduta é justa ou injusta". DAvID F. Houston, Eight Years with Wilson's Cabinet, 2 vols.; Doubleday, Page \& Co., 1926, II, 150 .

(35) Embora as notas de conferência, usadas por Wilson nos seus cursos de administração púb: $a$, mostrem a influência de escritores alemães e franceses, suas teorias políticas e administrativas se abeberaram primordialmente nos mestres inglêses.

(36) Como salientou WILliam DiAmond, os dois elementos principais do pensamento de Wilson, no seu período de magistério: “... foram uma firme fé no conservadorismo histórico e uma crença na harmonia social entre o individualismo e a competição... o primeiro haurido em BURKE, o filósofo do conservantismo político, e o segundo em ADAM SMITH, o sistematizador do liberalismo econômico". WILliam Diamond, The Economic Thought of Woodrow Wilson, Johns Hopkins Press, 1943, p. 57.

(37) WrLsON, em diversas ocasiões, aclamou a grandeza de HAMmLToN. Afirmou nos começos de 1910, que "... ninguém podia derrotar AlexANDER HAMILTON, estivesse fora ou no govêrno, porque só êle possuia programa construtivo de onde ter que seguir-se a HAMILTON ou aceitar o caos". Citado em BAKER, op. cit. II, 343. 
via, na primeira década dêste século, suas convicções econômicas e políticas sofreram transformação, e, assim, surgiu êle como um liberal do século $\mathrm{XX}$, defensor militante dos princípios políticos de Thomas Jefferson.

Com sua teoria evolutiva orgânica, fundamentada primacialmente em EDMUND BURKE, WILSON habilitou-se a tratar filosòficamente os negócios públicos, de modo que pôde acomodar opiniões políticas e econômicas, quando percebeu que suas tcorias não se harmonizavam com a época. Em seu período acadêmico, a filosofia de WILson - "os Estados são organismos vivos que se formam a uma lenta acumulação" - levou-c. a opor-se às diretrizes de BRYAN e de outros progressistas. Todavia, depois que com êles se associou, essa mesma teoria orgânica lhe permitiu raciocinar que, se as formas governamentais evoluiram até ao estágio presente, é lógico que modificações posteriores venham a ser adotadas. (38),

Embora a premência da guerra tenha sido, sem dúvida, o fator primordial que contribuiu para $c$ fracasso de WILSON em promover ativamente a reorganização do sistema administrativo do Govêrno Federal, essa transição política do hamiltonianismo para o jeffersonianismo é outro fator a ser considerado. Nos seus primeiros tempos, como partidário de HAMILTON, concentrou esforços na defesa de uma reorganização do govêrno, de modo a proporcionar liderança mais eficaz e maior eficiência e economia à administração. Todavia, à medida que foi adotando gradualmente a ideologia política de JEFFERson, passou a acreditar que as reformas sociais se tornavam mais urgentes.

A filosofia política e administrativa de WiLson era, portanto, uma síntese das idéias de JefFERson e de HAMiLton. Em estrita harmonia com a tradição jeffersoniana, acreditou que a vitalidade dos Estados Unidos repousava nas ccmunidades rurais; opôs-se à concentração de riqueza, e patenteou sua fé na sabedoria e honestidade intrínsecas do homem médio. Não obstante, suas idéias administrativas continuaram hamiltonianas. Defendeu a centralização do poder governamental; assegurou que havia pouco a temer de uma forte liderança executiva, se fôsse exercida de modo responsável; advcigou a concessãc de amplos poderes discricionários aos administradores, e insistiu para que também à administração se permitisse orientar o desenvolvimento social, mediante a iniciativa de projetos de leis. Assim, Wilson usaria meics hamiltonianos para atingir fins defendidos por JEFFERSON.

\section{APRECIAÇÃO GERAL}

Embora já três décadas hajam decorrido desde que WoodRow WiLson deixou a Casa Branca, o efeito integral de seu Govêrno sôbre nosso sistema administrativo não pode, ainda, ser definitivamente averiguado. Conquanto suas contribuições sejam, as mais das vêzes, evidentes, algumas de suas diretrizes e métodos têm sutis, mas evolventes implicações administrativas.

(38) Pouco antes do término do primeiro mandato, WILSON escreveu: “... Acredito que o mais puro conservantismo consiste em contılua adaptação". WILSON a JoHN B. KNOX, em 30 da outubro de 1916, citado em BAKER, op cit VI, 111. 
Wilson retirou o Partido Democrático de sua antiga pcsição liberal e defensora dos direitos estaduais e transformou-o nc partido do Estado empreendedor - o partido que advoga a ação positiva do Govêrno para promover a segurança e o bem-estar econômico dc povo. Ajudou a mudar a filosofia vigente nos Estados Unidos, do liberalismo econômico - com seu conceito negativo de liberdade - para o liberalismo igualitário de JEFFERSON. Seu New-Freedom preparou o terreno para o New Deal de FRANKLIN RooseVELT. Outros Presidentes talvez tenham desfrutado maior êxito ao governal conforme preceitos de eficiência e economia, mas poucos Chefes de Executivo norte-americanos atuaram de maneira tão profunda nos propósitos e funcionamento da administração federal.

Assim, ao caracterizarmos a posição de WILson no desenvolvimento histórico da administração pública nos Estadc's Unidos, devemos pender para uma concepção genérica de suas contribuições e influências. Ao programa de reforma social, à liderança na Guerra e à defesa da Liga das Nações, devem incorporar-se, quando postos em correta perspectiva, os métodos e as teorias administrativas de WILSON, a fim de que possamos alicerçar o seu conceito como um do's grandes presidentes norte-americanos. 